\title{
Zaczyny do uszczelniania otworów w warunkach niskich wartości gradientów ciśnienia szczelinowania skał oraz do prac rekonstrukcyjnych
}

\section{Cement slurries for sealing boreholes in conditions of low pressure gradients of rock fracturing and for workover jobs or operations}

\author{
Marcin Kremieniewski \\ Instytut Nafty i Gazu - Państwowy Instytut Badawczy
}

\begin{abstract}
STRESZCZENIE: Receptury o obniżonej gęstości to zaczyny najczęściej stosowane w warunkach występowania niskich wartości gradientów ciśnienia szczelinowania, w rejonie skał słabozwięzłych, chłonnych, lub podczas prowadzenia prac rekonstrukcyjnych odwiertu. Stosowanie zaczynów lekkich zawierających frakcje o wymiarach większych niż średnica ziaren cementu pozwala wyeliminować ewentualność przesiąkania cieczy uszczelniającej przez strukturę skały o znacznej chłonności. Odpowiednio dobrany zaczyn lekki na skutek niskiej wartości ciśnienia hydrostatycznego nie powoduje rozszczelinowania struktury skał słabozwięzłych. Jednak mimo licznych zalet zaczynu lekkiego pojawiają się również negatywne aspekty, do których w pierwszej kolejności można zaliczyć nadmierne frakcjonowanie. Takie zachowanie zaczynu jest niekorzystne, ponieważ powoduje tworzenie się niejednolitej struktury płaszcza cementowego po związaniu. W związku z powyższym głównym parametrem, któremu należy poświęcić najwięcej uwagi podczas projektowania receptury zaczynu lekkiego jest właśnie stabilność sedymentacyjna. W celu wyeliminowania nadmiernego frakcjonowania stosuje się środki, które pozwalają utrzymać w całej objętości cieczy zarobowej cząstki o różnej gęstości. Odpowiedni dobór jakościowy i ilościowy poszczególnych domieszek pozwala na uzyskanie zaczynu cementowego o optymalnych parametrach, dostosowanych do konkretnych warunków geologiczno-technicznych, który nie będzie ulegał sedymentacji, a powstały z takiej receptury płaszcz cementowy będzie posiadał porównywalne wartości badanych parametrów bez względu na miejsce pomiaru. Zagadnienia dotyczące receptur zaczynów o obniżonej gęstości z przeznaczeniem do uszczelniania otworów w warunkach niskich wartości gradientów ciśnienia szczelinowania oraz do prac rekonstrukcyjnych wymagają ciągłego doskonalenia i prowadzenia prac badawczych. W związku z powyższym w niniejszej publikacji omówiono wyniki prac badawczych nad opracowaniem nowych zaczynów przeznaczonych do uszczelniania otworów w warunkach jak wspomniano powyżej. Zaprojektowano 4 receptury zaczynów o obniżonej gęstości, których parametry porównywano do receptury kontrolnej. W trakcie realizacji prac badawczych użyto zarówno dotychczas stosowane, jak również nowe lekkie dodatki wypełniające i środki ograniczające nadmierne frakcjonowanie projektowanych receptur. Opracowano nowe receptury zaczynów dla warunków otworowych o temperaturze około $30^{\circ} \mathrm{C}$ i ciśnieniu około $5 \mathrm{MPa}$. Wykonane zostały badania frakcjonowania zaczynów i przeprowadzono badania parametrów decydujących o efektywności uszczelniania. W przypadku próbek stwardniałych zaczynów wykonano badania wytrzymałości na ściskanie oraz określono siłę związania (przyczepności) stwardniałego zaczynu cementowego z powierzchnią rury okładzinowej.
\end{abstract}

Słowa kluczowe: zaczyn cementowy, zaczyn lekki, cementowanie otworów wiertniczych, niski gradient szczelinowania, prace rekonstrukcyjne.

\begin{abstract}
The slurries most commonly used in the conditions of occurrence of low values of fracturing pressure gradients, in the area of weak, porous rocks, or during bore workover operations are reduced density recipes. The use of lightweight slurries containing fractions with dimensions larger than the diameter of cement grains allows to eliminate the possibility of seeping of sealing liquid through the rock structure with significant absorbency. Due to the low value of hydrostatic pressure properly selected, lightweight slurry doesn't cause fracturing of the structure of weak rocks. However, despite the numerous advantages of lightweight slurry, there are also negative aspects, which may include first of all excessive fractionation. This cement slurry behavior is disadvantageous because it causes the formation of a heterogeneous structure of the cement sheath after setting. Therefore, the main parameter that should be given the most attention when designing a lightweight cement slurry recipe is the sedimentation stability. In order to eliminate excessive fractionation, means that allow particles of different densities to be maintained in the entire volume of the liquid are used. Appropriate qualitative and quantitative selection of individual additives allows to obtain cement slurry with optimal properties, adapted to specific geological and technical conditions, which will not sediment. The resulting cement sheath will have comparable values of tested parameters regardless
\end{abstract}

Autor do korespondencji: M. Kremieniewski, e-mail: marcin.kremieniewski@inig.pl

Artykuł nadesłano do Redakcji: 6.11.2019 r. Zatwierdzono do druku: 28.01.2020 r. 
of the place of measurement. Issues regarding reduced density slurry recipes intended for sealing boreholes under low fracture pressure gradients and for workover operations require continuous improvement and research. Therefore, this publication discusses the results of research work on the development of new cement slurries for sealing holes under conditions mentioned above. Four low density cement slurry recipes were designed, whose parameters were compared with the control recipe. During the implementation of research works, both previously used as well as new lightweight fillers and measures to limit excessive fractionation of designed recipes were used. New slurry recipes have been developed for well conditions with a temperature of about $30^{\circ} \mathrm{C}$ and a pressure of about $5 \mathrm{MPa}$. Slurry fractionation were tested and parameters determining the sealing efficiency were studied. In the case of samples of hardened cement slurries, compressive strength tests were performed and the bonding strength (adhesion) of the hardened cement slurry with the surface of the casing pipe was determined.

Key words: cement slurry, lightweight slurry, well cementing, low fracturing gradient, workover jobs or operations.

\section{Wprowadzenie}

Uszczelnianie otworów w warunkach występowania niskich gradientów szczelinowania wymaga odpowiedniego dostosowania ciśnienia tłoczenia zaczynu cementowego. Niska wartość ciśnienia wytłaczanego zaczynu wiąże się z pominięciem występowania przepływu turbulentnego w przestrzeni pierścieniowej i z tłoczeniem przy zachowaniu warunków przepływu thokowego (Stryczek et al., 2014; Kremieniewski et al., 2017). Innymi metodami stosowanymi w warunkach niskich gradientów szczelinowania jest stosowanie metody wielostopniowego cementowania, bądź też stosowanie zaczynów o niskich wartościach gęstości, tzw. zaczynów lekkich oraz stosowanie lekkich płuczek wypełniających przestrzeń pierścieniową poza rurami okładzinowymi (Nelson, 1990; Gawlik i Szymczak, 2006;). Niewielkie wartości gradientów szczelinowania oraz występowanie skał chłonnych wymagają cementowania zaczynami lekkimi, które pozwalają na obniżenie ciśnienia hydrostatycznego słupa zaczynu poza rurami okładzinowymi i tym samym obniżenie ciśnienia tłoczenia poniżej wartości rozwarstwiania skał (Kremieniewski, 2018, 2019b, 2019d). Zaczyny o obniżonej gęstości są niekiedy stosowane podczas wykonywania prac rekonstrukcyjnych, gdy prowadzone są one w rejonie występowania niskich wartości gradientów szczelinowania. Głównym celem rekonstrukcji odwiertów eksploatacyjnych $\mathrm{w}$ górnictwie naftowym i gazownictwie jest przedłużenie czasu eksploatacji złoża lub wzrost wydobycia ropy i gazu przy jednoczesnym uzyskaniu jak największego sczerpania złoża węglowodorów (Ziaja i Wiśniowski, 2008). Powyższe można uzyskać wskutek zastosowania zabiegu stymulacji, pogłębienia odwiertu, udostępnieniu nowego poziomu produktywnego do eksploatacji, wymianę uszkodzonych rur okładzinowych bądź elementów wyposażenia wgłębnego (Uliasz i Dubiel, 2015). Do prac rekonstrukcyjnych można zaliczyć m.in. likwidowanie nieszczelności rur okładzinowych lub innych elementów odwiertu (Dubiel et al., 2012, 2015). Może się to odbywać poprzez docementowanie, uszczelnianie, które prowadzone jest właśnie przy użyciu zaczynów lekkich w rejonie skał chłonnych. Możliwe jest także wprowadzenie dodatkowych sekcji rur lub niekiedy nowej kolumny rur. W przypadku decyzji o uniknięciu kosztownego frezowania i wymiany rur na nowe, przy jednoczesnej konieczności utrzymania sprawności technicznej odwiertu w razie możliwości zapuszczana jest kolumna o mniejszej średnicy i cementowana w dotychczas istniejącej (Nelson, 1990).

Przy projektowaniu zaczynów przeznaczonych do uszczelniania otworów w warunkach niskich gradientów szczelinowania oraz do prac rekonstrukcyjnych stosuje się dodatki wypełniające, których gęstość jest znacznie niższa niż gęstość zaczynu. Wypełniacze o niskiej gęstości nasypowej pozwalają na obniżenie gęstości zaczynu z wartości ok. $1800 \mathrm{~kg} / \mathrm{m}^{3}$ do wartości około $1200 \mathrm{~kg} / \mathrm{m}^{3}$ (Kremieniewski, 2017b; Kremieniewski i Stryczek, 2019). Jednak stosowanie takich dodatków powoduje powstawianie pewnego rodzaju problemów. W trakcie uszczelniania kolumny rur okładzinowych zachodzą zjawiska sedymentacji fazy stałej wykazującej różne wartości gęstości oraz związany z tym odstój wody (rys. 1). W przypadku zaczynów lekkich mamy do czynienia $\mathrm{z}$ frakcjonowaniem zaczynu cementowego. Wartości tych parametrów wzrastają proporcjonalnie do wzrostu odchylenia osi odwiertu od pionu, co jest bardzo istotne podczas cementowania otworów kierunkowych w rejonie występowania niskich wartości gradientów szczelinowania. Należy mieć także na uwadze, że również w otworach pionowych zachodzi zjawisko frakcjonowania zaczynu (rys. 2). Cząsteczki o większej gęstości opadają na skutek sił grawitacji ze znacznie większą prędkością niż cząsteczki posiadające mniejszy ciężar (Stryczek et al., 2005; Peng i Jacobsen, 2013; Kremieniewski, 2017a). Zjawisko to obserwowane jest najczęściej w przypadku zwiercin w płuczce wiertniczej. Występuje ono jednak również w zaczynach zawierających materiały stosowane do regulacji gęstości. Rozwarstwianie się zaczynu cementowego w otworze pionowym zachodzi na długości kilku bądź kilkunastu metrów, w związku z czym jest trudne do zaobserwowania i bardziej widoczne jest to w przypadku otworów odchylonych od pionu. Dzieje się tak, ponieważ rozwarstwienie ma miejsce na długości kilkunastu centymetrów, czyli na długości równiej średnicy otworu. Z tego powodu jednorodność struktury cieczy wiertniczych jest bardzo 


\section{NAFTA-GAZ}

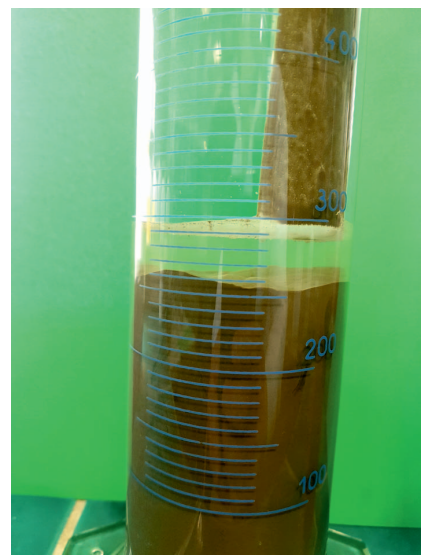

Rys. 1. Odstój wody w zaczynie o niskiej stabilności sedymentacyjnej

Fig. 1. Water retention in the slurry with low sedimentation stability

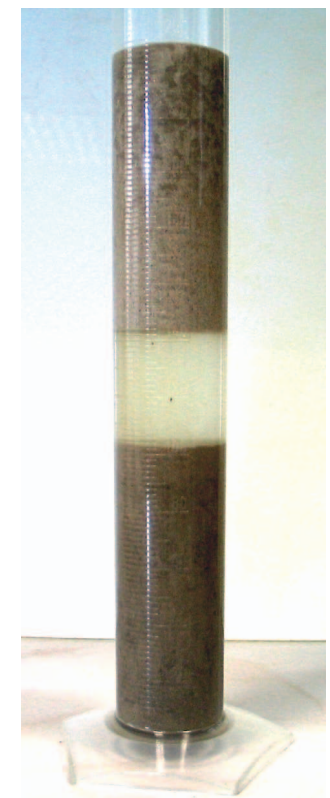

Rys. 2. Nadmierne frakcjonowanie zaczynu zawierającego lekki wypełniacz Fig. 2. Excessive fractionation of the cement slurry containing light filler

ważna, mimo iż w otworach pionowych nie widać tego zjawiska (Stryczek et al., 2016; Kremieniewski 2019a, 2019c). Zaczyn cementowy o niskiej stabilności sedymentacyjnej posiada w górnej części otworu wiertniczego niższą niż założona wartość gęstości, w związku z czym powstająca z takiego zaczynu struktura płaszcza cementowego wykazuje znaczną anizotropię. Płaszcz cementowy powstały z niejednorodnego zaczynu będzie wykazywał znaczne różnice $\mathrm{w}$ wartościach wytrzymałości mechanicznej, przyczepności do rur okładzinowych, porowatości oraz przepuszczalności w zależności od punktu pomiaru (Stryczek et al., 2009; Kremieniewski i Rzepka, 2017). Uwzględniając ponadto podwyższone wartości odstoju wody w zaczynie w górnej części otworu, można przyjąć, że po związaniu cementu przestrzeń ta stanowić będzie kanał wzdłuż kolumny rur (rys. 3), który umożliwi migrację mediów złożowych (Wiśniowski et al., 2009).

W związku z powyższym w celu zaprojektowania receptury zaczynu cementowego do uszczelniania otworów w warunkach niskich gradientów ciśnienia szczelinowania oraz do prac rekonstrukcyjnych główną uwagę należy poświęcić stabilności sedymentacyjnej zaczynu w fazie płynnej, co zostało

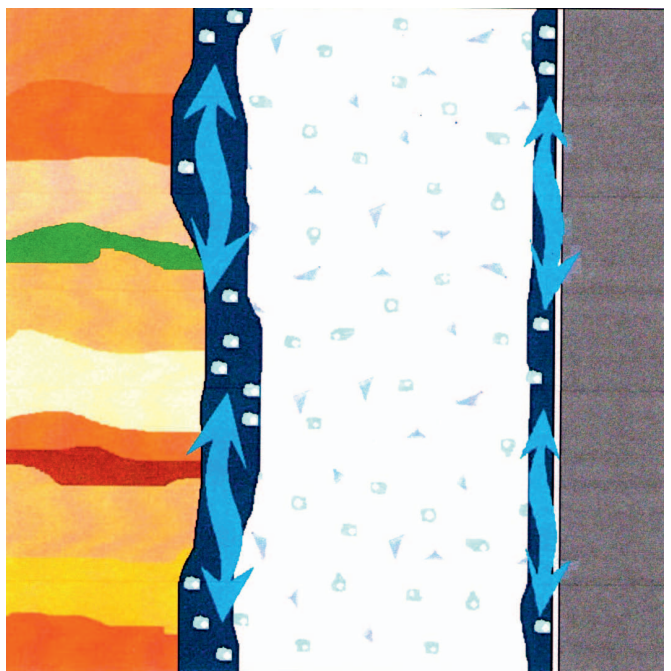

Rys. 3. Brak związania zaczynu cementowego z formacją skalną

Fig. 3. Lack of cement slurry binding with rock formation

przedstawione w dalszej części niniejszej publikacji. Jednak bardzo ważne jest również utrzymanie na wymaganym poziomie pozostałych parametrów decydujących o efektywności uszczelniania otworów wiertniczych.

\section{Przebieg prac badawczych}

Badania nad opracowaniem receptur zaczynów przeznaczonych do uszczelniania otworów w warunkach niskich gradientów szczelinowania oraz do prac rekonstrukcyjnych zostały zrealizowane w Laboratorium Zaczynów Uszczelniających INiG - PIB w oparciu o normy: PN-85/G-02320 Cementy $i$ zaczyny cementowe do cementowania w otworach wiertniczych; PN-EN 10426-2 Przemyst naftowy i gazowniczy. Cementy i materiaty do cementowania otworów. Część 2: Badania cementów wiertniczych oraz API SPEC 10 Specification for materials and testing for well cements.

W celu opracowania omawianych w niniejszej publikacji receptur zaczynów zastosowano odpowiednio dobrane dodatki i domieszki. Użycie tych środków pozwoliło uzyskać niską gęstość zaczynu przy jednoczesnym zachowaniu wymaganych wartości parametrów technologicznych dostosowanych do określonych warunków geologiczno-technicznych. Wyróżniono również dwie receptury $\mathrm{z}$ dodatkiem lateksu oraz dwa zaczyny bezlateksowe, które korzystnie jest stosować w trakcie prowadzenia prac rekonstrukcyjnych. Utrudnieniem podczas projektowania receptur zaczynów o obniżonej gęstości, było frakcjonowanie dodatków lekkich (mikrosfer) w górnej części zaczynu oraz wydzielanie się wody wolnej. Taki nadmiernie frakcjonujący zaczyn nie był stabilny pod kątem sedymentacyjnym i podczas pomiaru gęstości w poszczególnych punktach kolumny sedymentacyjnej (rys. 4) wykazywał 
on różne wartości gęstości. W celu poprawy stabilności sedymentacyjnej projektowanych zaczynów skoncentrowano się na odpowiednim doborze ilościowym poszczególnych dodatków i domieszek oraz zastosowano środki przeciwdziałające sedymentacji.

W trakcie opracowywania receptur zaczynów bardzo ważne było uzyskanie odpowiednio wysokich wartości wytrzymałości strukturalnej, przez co zaczyn nabierał cech zaczynu tiksotropowego, co korzystnie wpływało na jego stabilność sedymentacyjną i przydatność do uszczelniania rur okładzinowych w rejonie występowania niskich gradientów ciśnienia szczelinowania. Jednym z najważniejszych parametrów w omawianych zaczynach było określenie gęstości i jednocześnie uzyskanie odpowiedniej stabilności sedymentacyjnej. W trakcie kolejnych badań określone zostały parametry technologiczne zaczynu, które decydowały o efektywności uszczelniania, czyli: parametry reologiczne zaczynu, filtracja zaczynu w warunkach dynamicznych i czas gęstnienia w warunkach otworopodobnych. W tabeli 1 przedstawiono składy receptur zaczynów, natomiast w tabeli 2 - uzyskane parametry technologiczne zaczynów. Na potrzeby publikacji zamieszczone zostały najlepsze wyniki badań.

Receptury zaczynów cementowych przeznaczonych do uszczelniania otworów w warunkach niskich gradientów szczelinowania oraz do prac rekonstrukcyjnych zestawiono w tabeli 1. Zaczyn nr 1 $30^{\circ} \mathrm{C}$ i ciśnieniu około $5 \mathrm{MPa}$

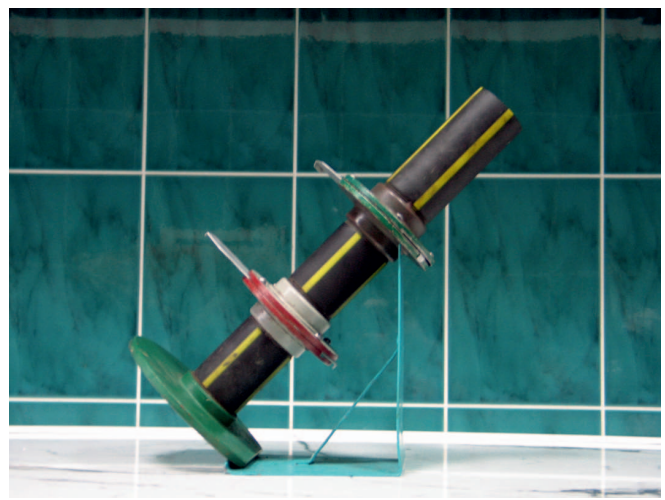

Rys. 4. Kolumna sedymentacyjna do badania stabilności sedymentacyjnej zaczynu cementowego

Fig. 4. Sedimentation column for testing the sedimentation stability of cement slurry

Tabela 1. Składy wytypowanych zaczynów dla warunków otworowych o temperaturze około

Table 1. Compositions of selected slurries for borehole conditions with a temperature of approx. $60^{\circ} \mathrm{C}$ and a pressure of about $5 \mathrm{MPa}$

\begin{tabular}{|c|c|c|c|c|c|}
\hline SKLAD & $\begin{array}{c}\text { ZACZYN 1 } \\
\text { bazowy }\end{array}$ & ZACZYN 2 & ZACZYN 3 & ZACZYN 4 & ZACZYN 5 \\
\hline \hline Woda wodociągowa & 0,80 & 1,0 & 0,9 & 1,0 & 0,9 \\
\hline Bentonit (bwow) & $1,0 \%$ & 2,0 & 1,5 & 1,0 & 0,5 \\
\hline Środek odpieniający & $1,0 \%$ & 0,5 & 0,5 & 0,5 & 0,5 \\
\hline Środek upłynniający & $0,3 \%$ & 0,3 & 0,3 & 0,3 & 0,35 \\
\hline Środek antyfiltracyjny & $0,5 \%$ & 0,4 & 0,4 & 0,4 & 0,3 \\
\hline CaCl $_{2}$ & $1,0 \%$ & 3,0 & 3,0 & 3,0 & $\mathbf{4 , 0}$ \\
\hline Lateks & $\mathbf{1 8 , 0} \%$ & - & $\mathbf{1 0 , 0}$ & - & 10,0 \\
\hline Stabilizator lateksu & $\mathbf{1 , 0 \%}$ & - & $\mathbf{1 , 0}$ & - & $\mathbf{1 , 0}$ \\
\hline Mikrosfera & $\mathbf{2 5 , 0} \%$ & $\mathbf{4 0 , 0}$ & $\mathbf{4 0 , 0}$ & - & - \\
\hline Perlit filtracyjny & - & - & - & $\mathbf{1 0 , 0}$ & $\mathbf{1 0 , 0}$ \\
\hline Mikrocement & $\mathbf{2 0 , 0} \%$ & - & - & - & - \\
\hline Cement CEM G & $100,0 \%$ & 100,0 & 100,0 & 100,0 & 100,0 \\
\hline
\end{tabular}

Tabela 2. Parametry technologiczne badanych receptur zaczynów dla warunków otworowych o temperaturze około $30^{\circ} \mathrm{C}$ i ciśnieniu około $5 \mathrm{MPa}$

Table 2. Technology parameters of the tested slurries for borehole conditions with a temperature of approx. $30^{\circ} \mathrm{C}$ and a pressure of about $5 \mathrm{MPa}$

\begin{tabular}{|c|c|c|c|c|c|c|}
\hline \multicolumn{2}{|l|}{ Parametr } & $\begin{array}{c}\text { ZACZYN } 1 \\
\text { bazowy }\end{array}$ & ZACZYN 2 & ZACZYN 3 & ZACZYN 4 & ZACZYN 5 \\
\hline \multicolumn{2}{|l|}{ Gęstość $\left[\mathrm{kg} / \mathrm{m}^{3}\right]$} & 1360 & 1260 & 1220 & 1300 & 1290 \\
\hline \multicolumn{2}{|l|}{ Odstój wody [\%] } & 0,4 & 0,0 & 0,0 & 0,0 & 0,0 \\
\hline \multicolumn{2}{|l|}{ Filtracja $\left[\mathrm{cm}^{3} / 30 \mathrm{~min}\right]$} & 42,0 & 214 & 99,0 & 116,0 & 91,0 \\
\hline \multicolumn{2}{|l|}{ Lepkość plastyczna $[\mathrm{mPa} \cdot \mathrm{s}]$} & 108,0 & 58,5 & 96,0 & 120,0 & 112,5 \\
\hline \multicolumn{2}{|l|}{ Granica płynięcia $[\mathrm{Pa}]$} & 5,76 & 30,0 & 13,9 & 13,9 & 13,2 \\
\hline \multicolumn{2}{|c|}{ Wytrzymałość strukturalna $[\mathrm{Pa}]$} & 9,3 & 38,2 & 22,4 & 22,4 & 21,1 \\
\hline \multirow{2}{*}{$\begin{array}{c}\text { Czas gęstnienia } \\
\left(\mathrm{t}=30^{\circ} \mathrm{C}^{*}, \mathrm{p}=5 \mathrm{MPa}\right) \\
{ }^{*} \text { Czas dojścia do temperatury w } 15 \text { minut }\end{array}$} & $30 \mathrm{Bc}$ & $4: 40$ & $4: 37$ & 3:00 & $5: 14$ & 4:00 \\
\hline & $100 \mathrm{Bc}$ & $5: 40$ & $5: 12$ & $5: 18$ & $5: 49$ & $4: 56$ \\
\hline
\end{tabular}


to receptura zastosowana do uszczelniania otworu Gi $2 \mathrm{H}$ i recepturę tę przyjęto jako zaczyn kontrolny w celu porównawczym. Do sporządzenia tego zaczynu użyto $18 \%$ lateksu, 25\% mikrosfer glinokrzemianowych i $20 \%$ mikrocementu jako wypełniacza przestrzeni międzyziarnowej. Zaczyny nr 2 oraz 3 to receptury, w których gęstość regulowano poprzez dodanie $40 \%$ mikrosfer glinokrzemianowych i nie zastosowano mikrocementu, przy czym zaczyn 2 to zaczyn bez lateksu, a zaczyn 3 zawierał dodatek lateksu. $Z$ kolei receptury 4 i 5 to zaczyny $\mathrm{z}$ dodatkiem 10\%-owej koncentracji perlitu filtracyjnego, przy czym analogicznie jak w poprzednich dwóch recepturach zaczyn nr 4 to zaczyn bez lateksu, a zaczyn nr 5 to zaczyn z dodatkiem lateksu. Wszystkie receptury sporządzono dla warunków otworowych o temperaturze około $30^{\circ} \mathrm{C}$ i ciśnieniu około $5 \mathrm{MPa}$.

Receptura kontrolna nr 1 zawierała 18\% lateksu oraz $25 \%$ mikrosfer w celu obniżenia gęstości. Zastosowano również 20\% mikrocementu, którego zadaniem było doszczelnienie matrycy cementowej (tab. 1). Zaczyn nr 1 posiadał gęstość $1360 \mathrm{~kg} / \mathrm{m}^{3}$ i posiadał 0,4\% wody wolnej (odstój). Zaczyn nie był stabilny sedymentacyjnie i w trakcie pomiaru gęstości w trzech punktach pomiarowych kolumny sedymentacyjnej uzyskano wartość $1340 \mathrm{~kg} / \mathrm{m}^{3}$ w części górnej, $1350 \mathrm{~kg} / \mathrm{m}^{3}$ w części środkowej oraz $1390 \mathrm{~kg} / \mathrm{m}^{3}$ w dolnej, co przedstawiono na rysunku 5. Brak stabilności związany z nadmiernym frakcjonowaniem zaczynu znajduje potwierdzenie w niskich wartościach parametrów reologicznych zaczynu bazowego, którego krzywa płynięcia posiadała najniższy z analizowanych zaczynów przebieg (rys. 6). W recepturze tej wartość granicy płynięcia wynosiła 5,76 Pa, a wytrzymałość strukturalna YP była równa 9,3 Pa. Obecność dodatku mikrocementu wpłynęła na uzyskanie niskiej wartości filtracji zaczynu w warunkach dynamicznych, która wynosiła $42 \mathrm{~cm}^{3} / 30 \mathrm{~min}$. Wyniki zrealizowanych badań zestawiono w tabeli 2 i na rysunkach 5 i 6 .

Zaczyn nr 2 zawierał większą (40\%-ową) ilość mikrosfer. Ze względu na brak dodatku lateksu, który zwiększa lepkość to w recepturze tej (w celu poprawy stabilności sedymentacyjnej) zastosowano $2 \% \mathrm{BWOW}^{1}$ bentonitu. Użyto $3 \%$ chlorku wapnia w celu skrócenia czasu wiązania. O otrzymanie wymaganych wartości parametrów reologicznych zadbano natomiast stosując 0,3\%-ową ilość środka dyspergującego. W zaczynie

${ }^{1} \mathrm{BWOW} z$ ang. by weight of water - w stosunku do ilości wody zarobowej w zaczynie. nie użyto mikrocementu (tab. 1). Zaprojektowany zaczyn posiadał niższą gęstość niż zaczyn kontrolny $\left(1260 \mathrm{~kg} / \mathrm{m}^{3}\right)$. Uzyskanie tak niskich wartości gęstości zwiększa prawdopodobieństwo wystąpienia sedymentacji. Podczas pomiaru tego parametru zaczyn posiadał jednakże odpowiednią stabilność sedymentacyjną i we wszystkich punktach poboru próbki (góra, środek, dół) uzyskano tę samą wartość gęstości (rys. 5). Potwierdzeniem odpowiedniej stabilności sedymentacyjnej był również brak odstoju wody (tab. 2). Uzyskanie jednorodnej struktury zaczynu możliwe było dzięki odpowiednio dobranym parametrom reologicznym, gdzie krzywa płynięcia zaczynu przedstawiona na rysunku 6, posiadała najwyższy przebieg w niskich szybkościach ścinania. Wytrzymałość strukturalna zaczynu wynosiła 38,2 Pa. Niestety ze względu na znaczną ilość mikrosfer oraz brak dodatku lateksu, filtracja zaczynu była znacznie wyższa niż w recepturze kontrolnej i wynosiła $214 \mathrm{~cm}^{3} / 30 \mathrm{~min}$. 
W kolejnej recepturze oznaczonej nr 3 w celu obniżenia wartości filtracji przy jednoczesnym utrzymaniu optymalnych wartości pozostałych parametrów wprowadzono 10\%-ową ilość lateksu oraz zredukowano współczynnik wodno-cementowy, a także zmniejszono ilość bentonitu (tab. 1). Wprowadzone modyfikacje skutkowały osiągnięciem jeszcze niższej gęstości, która wynosiła $1220 \mathrm{~kg} / \mathrm{m}^{3}$, przy jednoczesnym zachowaniu wymaganej stabilności sedymentacyjnej (rys. 5), mimo zmniejszenia wartości wytrzymałości strukturalnej do 22,4 Pa (tab. 2). Zaczyn nie posiadał odstoju wody, a filtracja została zredukowana do wartości wynoszącej $99 \mathrm{~cm}^{3} / 30$ minut.

Następny zaczyn nr 4 to receptura, w której do obniżenia gęstości zastosowano dodatek perlitu filtracyjnego - był to zaczyn bez lateksu (tab. 1). Zaczyn $\mathrm{z}$ dodatkiem $10 \%$ perlitu posiadał gęstość równą $1300 \mathrm{~kg} / \mathrm{m}^{3}$. Gęstość jest niewiele wyższa niż w poprzednich recepturach, ale w tym składzie zastosowano tylko $10 \%$ perlitu, co jest bardzo korzystne z ekonomicznego punktu widzenia. Zaczyn ten posiadał jednakowe wartości w poszczególnych punktach pomiaru podczas badania stabilności sedymentacyjnej (rys. 5) i nie wykazywał odstoju wody. Zastosowanie perlitu, który wykazuje właściwości wodożądne skutkowało uzyskaniem filtracji równej $116 \mathrm{~cm}^{3} / 30 \mathrm{~min}$ (w porównaniu do wartości $214 \mathrm{~cm}^{3} / 30 \mathrm{~min}$ dla zaczynu bezlateksowego z dodatkiem 40\% mikrosfer glinokrzemianowych) (tab. 2).

W kolejnej recepturze na bazie perlitu, oznaczonej nr 5 zastosowano 10\%-ową ilość lateksu oraz zmniejszono współczynnik wodno-cementowy. Zastosowano także 0,5\% (BWOW) ilość bentonitu oraz 4\% chlorku wapnia w celu uzyskania wymaganego czasu gęstnienia zaczynu. Skład zaczynu przedstawiono $\mathrm{w}$ tabeli 1 . Wprowadzenie niniejszych modyfikacji skutkowało obniżeniem wartości filtracji z poprzedniej receptury i uzyskano $91 \mathrm{~cm}^{3} / 30 \mathrm{~min}$. Zaczyn posiadał gęstość $1290 \mathrm{~kg} / \mathrm{m}^{3}$ i wartość ta była stała niezależnie od punktu poboru próbki z poszczególnych części kolumny sedymentacyjnej (rys. 5). Paramtery reologiczne zaczynu były prawidłowe (tab. 2), a przebieg krzywej płynięcia przedstawiono na rysunku 6.

Mając na uwadze fakt, że projektowane receptury mogą znajdować zastosowanie również podczas prowadzenia prac rekonstrukcyjnych to znaczną uwagę poświęcono analizie parametrów mechanicznych - głównie wytrzymałości na ściskanie oraz przyczepności do rur stalowych. Analizując uzyskane wyniki wartości parametrów mechanicznych (rys. 7) stwierdzono, że wszystkie nowe receptury zaczynów (nr 2 do nr 5) posiadały wyższe wartości wytrzymałości na ściskanie niż próbka kontrolna. Stwierdzono również, że najwyższe spośród analizowanej grupy wartości wytrzymałości posiadały próbki stwardniałego zaczynu powstałego z receptur zaczynów nr 4 i nr 5. Są to zaczyny zawierające dodatek perlitu filtracyjnego, przy czym wartości wytrzymałości stwardniałego zaczynu nr 4 były wyższe niż zaczynu nr 5 .

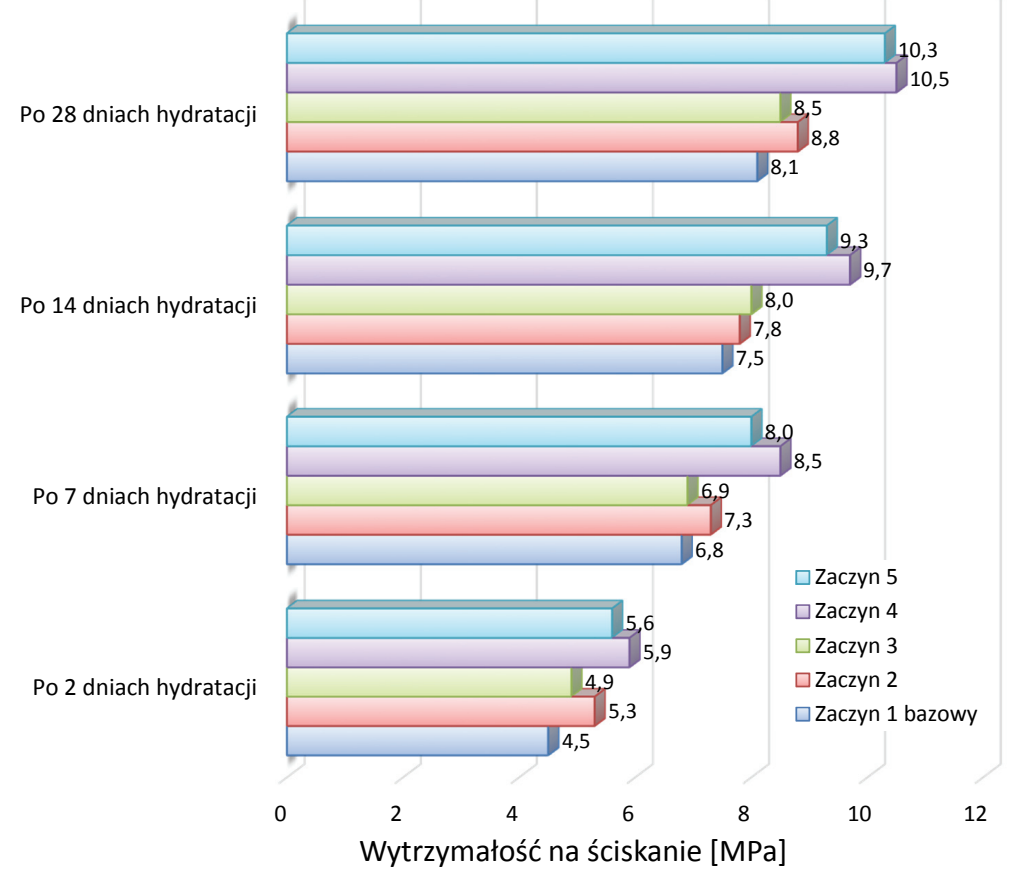

Rys. 7. Porównanie uzyskanych wartości wytrzymałości na ściskanie

Fig. 7. Comparison of obtained compressive strength values

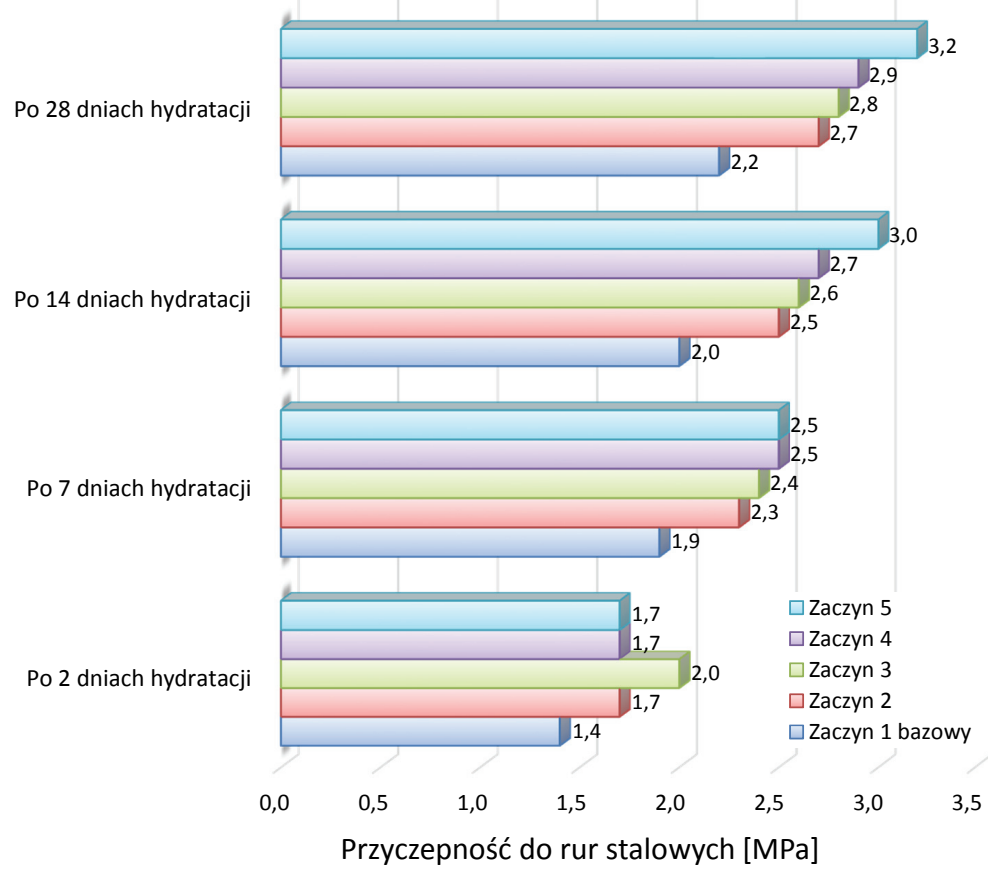

Rys. 8. Porównanie uzyskanych wartości przyczepności do rur stalowych

Fig. 8. Comparison of obtained adhesion values for steel pipes 
Obserwując uzyskane wyniki stwierdzono, że w przypadku receptur zaczynów zawierających dodatek mikrosfer glinokrzemianowych, zaczyn bez dodatku lateksu (nr 2) posiadał wyższe wytrzymałości niż zaczyn zawierający dodatek lateksu (nr 3). Na podstawie powyższego można stwierdzić, że w przypadku zaczynów lekkich dodatek lateksu powodował nieznaczne obniżenie wartości wytrzymałości na ściskanie. Wyniki zestawiono na rysunku 7.

Z kolei analizując wartości przyczepności stwardniałego zaczynu do rur stalowych (rys. 8) zaobserwowano, że najwyższe wartości uzyskano w przypadku próbek z zaczynu nr 5, w której to recepturze zastosowano dodatek perlitu filtracyjnego i był to zaczyn lateksowy. Jedynym odstępstwem od tej reguły był pomiar przyczepności w początkowym okresie hydratacji (2 dni), gdzie odnotowano najwyższą wartość w przypadku zaczynu oznaczonego numerem 3. Był to zaczyn z dodatkiem mikrosfer glinokrzemianowych, ale receptura ta również zawierała dodatek lateksu. Wszystkie z analizowanych próbek zaczynów posiadały wyższe wartości przyczepności niż próbka bazowa. Wyniki zestawiono na rysunku 8.

\section{Wniosk}

Na podstawie zrealizowanych prac badawczych sformułowano następujące wnioski końcowe:

- dodatek lateksu w zaczynie cementowym o obniżonej gęstości powodował obniżenie wartości filtracji;

- parametry reologiczne zaczynu cementowego (głównie wartość wytrzymałości strukturalnej i granicy płynięcia) decydują o stabilności sedymentacyjnej;

- zastosowanie około $10 \%$ do $12 \%$ dodatku ekspandowanego perlitu filtracyjnego w celu obniżenia gęstości zaczynu może być traktowane jako ekwiwalent ok. 40\% dodatku mikrosfery glinokrzemianowej. Tym samym w przypadku receptur zaczynów przeznaczonych do rekonstrukcji, perlit może być bardziej ekonomiczną alternatywą lekkiego dodatku wypełniającego;

- filtracja zaczynów z dodatkiem perlitu filtracyjnego (receptura nr 4 i nr 5; tab. 2) była niższa niż w recepturach zaczynów z dodatkiem mikrosfer glinokrzemianowych (nr 2 i nr 3; tab. 2);

- lepkości plastyczne zaczynów modyfikowanych dodatkiem perlitu filtracyjnego wykazywały wyższe wartości niż w przypadku zaczynów, w których do obniżenia gęstości zastosowano dodatek mikrosfer glinokrzemianowych;

- dodatek perlitu filtracyjnego do zaczynów przeznaczonych dla warunków o temp. $30^{\circ} \mathrm{C}$ i ciśnienia $5 \mathrm{MPa}$ powodował nieznaczne wydłużenie czasu gęstnienia zarówno zaczynu z dodatkiem lateksu, jak i zaczynu bezlateksowego;
- próbki stwardniałych zaczynów, w których do obniżenia gęstości zastosowano 10\%-owy dodatek perlitu filtracyjnego posiadały wyższe wartości parametrów mechanicznych (wytrzymałości na ściskanie i przyczepności do rur stalowych) niż receptury zaczynów, w których do obniżenia gęstości zastosowano 40\%-ową ilość dodatku mikrosfer glinokrzemianowych;

- dodatek lateksu w analizowanej grupie receptur zaczynów o obniżonej gęstości powodował obniżenie wartości wytrzymałości na ściskanie;

- analizując wartości przyczepności płaszcza cementowego do stali, zaczyny zawierające dodatek lateksu posiadały wyższe wartości przyczepności niż odpowiadające im zaczyny bez dodatku lateksu;

- zaproponowane receptury zaczynów o obniżonej gęstości mogą być przeznaczone i stosowane do uszczelniania otworów w warunkach niskich gradientów szczelinowania oraz do prac rekonstrukcyjnych. Zaczyny te $\mathrm{z}$ dodatkiem zarówno mikrosfer ceramicznych, jak i perlitu filtracyjnego nie ulegały frakcjonowaniu, czego dowodem było uzyskanie odpowiedniej stabilności sedymentacyjnej (rys. 5).

Artykuł powstał na podstawie prac badawczych pt.: Analiza możliwości poprawy stabilności sedymentacyjnej zaczynów cementowych - praca INiG - PIB na zlecenie MNiSW; nr zlecenia: 0036/ KW/2016, nr archiwalny: DK-4100/0036/2016 oraz Analiza możliwości doszczelnienia mikrostruktury płaszcza cementowego za pomoca nowych domieszek drobnoziarnistych - praca INiG - PIB na zlecenie MNiSW; nr zlecenia: 0044/KW/2019, nr archiwalny: DK-4100/0034/2019.

\section{Literatura}

Dubiel S., Luboń K., Luboń W., Wartak W., 2012. Problemy rekonstrukcji odwiertów geotermalnych na przykładzie odwiertu Biały Dunajec PAN-1. AGH Drilling, Oil, Gas, 29: 115-126.

Dubiel S., Ulisz-Misiak B., Ziaja J., Stachowicz K., 2015 Problemy bezpieczeństwa prac podczas rekonstrukcji odwiertów eksploatacyjnych. Przegląd Górniczy, 12: 106-115.

Gawlik P., Szymczak M., 2006. Migracje gazowe w przestrzeniach międzyrurowych otworów realizowanych na przedgórzu Karpat. Nafta-Gaz, 7-8: 349-358.

Kremieniewski M., 2017a. Poprawa stabilności sedymentacyjnej zaczynu cementowego. Nafta-Gaz, 4: 242-249. DOI: 10.18668/ NG.2017.04.04

Kremieniewski M., 2017b. Wpływ perlitu pylistego na własności technologiczne zaczynu cementowego. Nafta-Gaz, 12: 943-952. DOI 10.18668/NG.2017.12.05.

Kremieniewski M. 2018 Poprawa wczesnej wytrzymałości mechanicznej płaszcza cementowego powstałego z zaczynu lekkiego. Nafta-Gaz, 8: 599-605. DOI: 10.18668/NG.2018.08.06.

Kremieniewski M., 2019a. Korelacja wyników badań filtracji i wczesnej wytrzymałości mechanicznej zaczynów cementowych z dodatkiem mączki krzemionkowej. Nafta-Gaz, 7: 394-403. DOI 10.18668/NG.2019.07.03

Kremieniewski M., 2019b. Receptury zaczynów do uszczelniania kolumn rur posadowionych w otworach wierconych 
w skałach chłonnych. Nafta-Gaz, 8; 451-457. DOI: 10.18668/ NG.2019.08.01.

Kremieniewski M., 2019c. Rola plastyfikatora w projektowaniu zaczynu lekkiego o podwyższonej stabilności sedymentacyjnej. Nafta-Gaz, 9: 571-578. DOI: 10.18668/NG.2019.09.06.

Kremieniewski M., 2019d. Korelacja wyników badań wytrzymałości na ściskanie i przyczepności do rur stalowych płaszcza cementowego z zaczynu o obniżonej gęstości. Nafta-Gaz, 10: 613-624. DOI: $10.18668 /$ NG.2019.10.03.

Kremieniewski M., Rzepka M., 2017. Celowość prowadzenia prac badawczych nad nowymi środkami obniżającymi filtrację zaczynów cementowych. Nafta-Gaz, 8: 583-590. DOI: 10.18668/ NG.2017.08.05.

Kremieniewski M., Stryczek S., 2019. Zastosowanie cementu wysokoglinowego do sporządzania zaczynów uszczelniających w technologiach wiertniczych. Cement Wapno Beton, 3: 215-226.

Kremieniewski M., Stryczek S., Wiśniowski R., Rzepka M., Gonet A., 2017. Wpływ dodatku montmorylonitu (bentonitu) na parametry świeżego i stwardniałego zaczynu cementowego. AGH Drilling, Oil, Gas, 34: 323-334.

Nelson E.B. (ed.), 1990. Well Cementing. Schlumberger Educational Service, Houston, Teksas, USA.

Peng Y., Jacobsen S., 2013. Influence of water/cement ratio, admixtures and filler on sedimentation and bleeding of cement paste. Cement and Concrete Research, 54: 133-142. DOI: 10.1016/j. cemconres.2013.09.003.

Stryczek S., Gonet A., Wiśniowski R., 2005. Wpływ wybranego dodatku mineralnego na własności technologiczne zaczynów cementowych. Wiertnictwo, Nafta, Gaz, 22/1: 333-341.
Stryczek S., Wiśniowski R., Gonet A., Ferens W., 2009. Parametry reologiczne świeżych zaczynów uszczelniających w zależności od czasu ich sporządzania. Wiertnictwo, Nafta, Gaz, 26/1-2: 369-382.

Stryczek S., Wiśniowski R., Gonet A., Złotkowski A., 2014. The influence of time of rheological parameters of fresh cement slurries. AGH Drilling, Oil, Gas, 31: 123-133 DOI 10.7494/ drill.2014.31.1.123.

Stryczek S. (red.), Wiśniowski R., Uliasz-Misiak B., Złotkowski A., Kotwica Ł., Rzepka M., Kremieniewski M., 2016. Studia nad doborem zaczynów uszczelniających w warunkach wierceń w basenie pomorskim. Wydawnictwo AHG. Kraków.

Uliasz B. M., Dubiel S. 2015 Problemy rekonstrukcji odwiertów geotermalnych. Przeglad Górniczy 7: 55-61.

Wiśniowski R., Stryczek S., Skrzypaszek K., 2007. Kierunki rozwoju badań nad reologią płynów wiertniczych. Wiertnictwo, Nafta, Gaz, 24: 595-607.

Ziaja J., Wiśniowski R., 2008. Analiza przyczyn występowania awarii przy pracach rekonstrukcyjnych z użyciem coiled tubingu. Wiertnictwo, Nafta, Gaz, 25: 807-812.

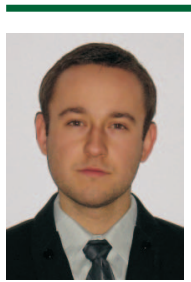

Dr inż. Marcin KREMIENIEWSKI

Adiunkt w Zakładzie Technologii Wiercenia Instytut Nafty i Gazu - Państwowy Instytut Badawczy ul. Lubicz 25 A

31-503 Kraków

E-mail:marcin.kremieniewski@inig.pl

\section{OFERTA BADAWCZA ZAKŁADU TECHNOLOGII WIERCENIA}

opracowywanie składów i technologii sporządzania ptuczek wiertniczych, cieczy do dowiercania, opróbowania i rekonstrukcji odwiertów, zaczynów cementowych i mieszanin wiążących dla różnych warunków geologiczno-technicznych wiercenia;

- kompleksowe badania i ocena nowych rodzajów środków chemicznych, materiatów ptuczkowych i wiążących, przeznaczonych do sporządzania i regulowania wtaściwości ptuczek wiertniczych i zaczynów cementowych;

pomiary parametrów technologicznych cieczy wiertniczych i kamienia cementowego w warunkach HPHT;

badania wptywu cieczy wiertniczych na przewiercane skaty;

- dobór ptuczek wiertniczych, zaczynów cementowych, cieczy buforowych w celu poprawy skuteczności cementowania otworów wiertniczych;

badania serwisowe dla bieżących zabiegów cementowania;

specjalistyczne badania laboratoryjne dotyczące oznaczania: wspótczynnika tarcia cieczy wiertniczych i napięcia powierzchniowego na granicy faz, czystości i temperatury krystalizacji solanek, typu emulsji, sedymentacji fazy statej, efektywności wynoszenia zwiercin w otworach kierunkowych i poziomych oraz wyptukiwania osadów itowych ze skat przed zabiegiem cementowania, odporności na migrację gazu w wiążącym zaczynie cementowym w warunkach otworopodobnych, wczesnej wytrzymatośc na ściskanie kamienia cementowego, odporności korozyjnej kamienia cementowego w różnym środowisku złożowym, porowatości oraz przepuszczalności dla gazu kamienia cementowego i skat, zawartości związków chemicznych w cieczach wiertniczych, stopnia toksyczności środków chemicznych i cieczy wiertniczych przy użyciu bioindykatorów;

badania wtaściwości fizyczno-mechanicznych skat pod kątem ich zwiercalności.

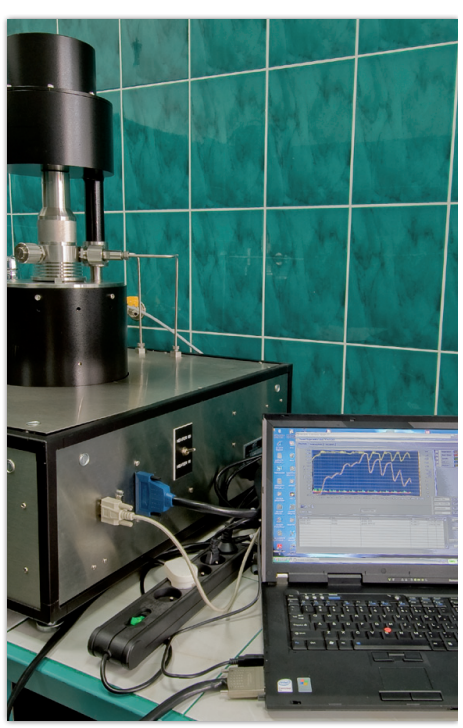

INSTYTUT NAFTY I GAZU

-Państwowy Instytut Badawczy 